\title{
Interferensi Leksikal pada Vlog Kenta Manis Channel berjudul "Kenta Pamit, Semua Nangis Denger Surat dari Kenta"
}

\author{
Ningrum Tresnasari ${ }^{1}$; Faizal Muhammad Akbar ${ }^{2}$; Naufal Muhammad Rafif 3 ; Raditya Jagadhita ${ }^{4}$ \\ Universitas Widyatama, Bandung, Jawa Barat, Indonesia \\ ningrum.tresnasari@widyatama.ac.id ${ }^{1}$, faizal.muhammad@widyatama.ac.id ${ }^{2}$, \\ $\underline{\text { naufal.rafif@widyatama.ac.id }}{ }^{3}$, rjagadhita@gmail.com $^{4}$
}

\begin{abstract}
Abstrak
Interferensi leksikal merupakan kasus yang paling sering dijumpai dalam masyarakat tutur. Hal ini terjadi ketika penutur (terlepas dari penutur asing atau penutur asli) mengalami keterbatasan kosakata atau tidak mengetahui padanan kosakata yang tepat dalam bahasa tertentu. Tujuan dari penelitian ini adalah untuk mengidentifikasi bentuk-bentuk interferensi leksikal yang terdapat dalam vlog saluran kenta manis yang berjudul "Kenta Pamit, All Nangis Denger Surat dari Kenta". Metode penelitian yang digunakan adalah metode deskriptif dengan pendekatan kualitatif, metode observasi dan metode analisis yang digunakan adalah metode ortografi ekuivalen. Sumber data yang digunakan dalam penelitian ini berasal dari vlog YouTube channel Kenta Manis. Jumlah total data interferensi leksikal dalam penelitian ini adalah 8 buah data. Dari analisis yang telah dilakukan, dapat disimpulkan bahwa interferensi leksikal oleh Kenta dalam vlognya terbagi menjadi dua klasifikasi, yaitu terdapat 7 interferensi leksikal dalam bahasa Inggris dan 1 interferensi leksikal dalam bahasa Mandarin.
\end{abstract}

Kata Kunci : Interferensi, Leksikal, Vlog

\begin{abstract}
Lexical interference is the case most often encountered in the speech community. This occurs when speakers (regardless of foreign or native speakers) experience vocabulary limitations or do not know the exact vocabulary equivalent in a particular language. The purpose of this study was to identify the forms of lexical interference contained in the kenta manis channel vlog entitled "Kenta Pamit, All Nangis Denger Surat from Kenta". The research method used is descriptive qualitative data collection methods observation method and the method of analysis used is the orthographic equivalent method. The data source used in this study came from the YouTube vlog of Kenta Manis channel. The total amount of lexical interference data in the study was 8 pieces of data. From the analysis that has been done, it can be concluded that lexical interference by kenta in his vlog is divided into two classifications, namely there are 7 lexical interference in English and 1 lexical interference in Chinese.
\end{abstract}

Keywords : Interference, Lexical, Vlog

\section{Pendahuluan}

Manusia adalah makhluk sosial yang bergantung terhadap manusia yang lain dimana manusia berkomunikasi untuk menjalin suatu hubungan. Bahasa merupakan salah satu cara manusia berkomunikasi satu sama lain. Di dunia terdapat jutaan bahasa 
yang digunakan untuk berkomunikasi dalam segala bidang seperti pendidikan, pekerjaan, bisnis, berwisata, dan kehidupan sehari-hari lainnya. Selain itu, kemampuan berbahasa menjadi syarat penting bagi seseorang untuk menjalankan aktifitasnya di luar negeri seperti bersekolah atau bekerja disuatu perusahaan sehingga dituntut untuk bisa berbahasa sesuai negara yang dituju. Dikutip dari website Listverse (https://listverse.com), Bahasa Indonesia menduduki peringkat ke-sembilan sebagai bahasa yang banyak dipelajari dengan jumlah 159 juta penutur.

Penutur bahasa asing yang menekuni bahasa Indonesia berbeda dengan bahasa awal ataupun bahasa ibu (mother tongue) kerap mengalami kesalahan dalam sebagian aspek semacam aspek menulis, membaca, menyimak, serta berdialog. Hal ini membuat penutur asing merasa kesulitan dalam berkomunikasi dengan teman yang berbeda bahasanya. Hal ini sesuai dengan pernyataan yang dikemukakan Setyawati (2010:246) bahwa kesalahan berbahasa dapat terjadi karena adanya banyak hal misalnya 1) pengaruh bahasa pertama, 2) kekurangan pemakai bahasa terhadap bahasa yang dipakainya, dan 3) pengajaran bahasa yang kurang sempurna. Selanjutnya, Kushartanti (2005:246) mengemukakan bahwa kontak bahasa dapat menjadi faktor penyebab terjadinya kesalahan berbahasa, sebab kontak bahasa berdampak kepada terbentuknya masyarakat dwibahasa atau multibahasa. Dalam ruang lingkup linguistik, kesalahan ataupun gangguan itu disebut interferensi.

Kesalahan berbahasa yang menjadi titik fokus peneliti adalah aspek interferensi leksikal dimana sering terjadi pada penutur asing atau penutur asli (native speaker) yakni keterbatasan penutur dalam kosakata bahasa sasaran. Dengan demikian penutur sering menyisipkan leksikal bahasa ibu atau bahasa asing ke dalam bahasa Indonesia, karena ketidaktahuan penutur bahwa bahasa Indonesia memiliki padanan dalam bahasa tersebut atau memang bahasa Indonesia tidak memiliki padanan yang tepat untuk kosakata yang dilafalkan.

Hal ini mendorong peneliti untuk meneliti lebih jauh tentang bentuk-bentuk interferensi leksikal dalam vlog Kenta Manis Channel berjudul "Kenta pamit, semua nangis denger surat dari Kenta".

\section{Metode dan Teori}

\subsection{Metode Penelitian}


Penelitian ini merupakan jenis penelitian deskriptif kualitatif dengan sumber data yang diambil dari vlog Kenta Manis Channel berjudul "Kenta pamit, Semua Nangis Denger Surat Dari Kenta” dengan link https://www.youtube.com/watch?v=94JHOVk9Orw. Metode pengumpulan data yang digunakan adalah metode simak dengan teknik simak bebas libat cakap dan metode analisis yang digunakan yaitu metode padan ortografis dengan teknik daya pilah ortografis. Jumlah data interferensi leksikal yang ditemukan oleh peneliti berjumlah 8 buah. Seluruh data yang ditemukan akan penulis paparkan dalam bab analisis.

\subsection{Teori}

\subsubsection{Interferensi}

Pada hakikatnya interferensi adalah peristiwa masuknya unsur bahasa yang satu ke dalam bahasa yang lain. Interferensi ini sering terjadi pada pengguna bahasa yang menguasai lebih dari satu bahasa. Tanpa disadari pada saat berbicara unsur bahasa lain akan masuk dalam bahasa yang digunakan. Seperti yang dikemukakan Kridalaksana (1974: 26) interferensi adalah penyimpangan dari kaidah-kaidah suatu bahasa yang terjadi pada orang bilingual (dwibahasawan) sebagai akibat penguasaan dua bahasa. Interferensi ini ada kaitannya dengan istilah identifikasi antarbahasa. Seorang bilingual mungkin melakukan identifikasi antarbahasa, yaitu memperserupakan hal-hal tertentu antara bahasa pertama dengan bahasa kedua (Rusyana, (1988: 6)). Sebagai akibatnya pada waktu ia berbicara atau menulis ia akan melakukan pencampuran kedua sistem bahasa itu, maka tejadilah interferensi. Penyebab interferensi yang lain adalah kurangnya penguasaan kidah-kaidah kebahasaan secara benar, ketidaktahuan penggunaan bahasanya sendiri, sehingga ia akan menggunakan bahasa itu semaunya sendiri tanpa mempedulikan kaidah yang benar.

\subsubsection{Interferensi Leksikal}

Menurut Aslinda dan Leni (2007:73) menyatakan bahwa interferensi dalam bidang leksikal terjadi apabila seorang dwibahasawan dalam peristiwa tutur memasukkan leksikal bahasa pertama ke dalam bahasa kedua atau sebaliknya. Interferensi ini terjadi karena pemindahan morfem atau kata bahasa pertama ke dalam pemakaian bahasa 
kedua. Bisa juga terjadi perluasan pemakaian kata bahasa pertama, yakni memperluas makna kata yang sudah ada sehingga kata dasar tersebut memperoleh kata baru.

Menurut teori tentang interferensi yang dikemukakan oleh Chaer dan Agustina (2010:126) bahwa kontribusi utama dari interferensi adalah dalam bidang kosakata atau leksikal karena pemakaian suatu bahasa secara luas dan mempunyai kosakata yang relatif banyak seperti bahasa Inggris akan memberikan kontribusi kosakata kepada bahasa-bahasa yang berkembang seperti bahasa Indonesia. Chaer (2003:263) juga mengatakan bahwa interferensi yang tampak menonjol adalah interferensi dalam bidang fonologi dan leksikon karena kita dengan mudah dapat menebak seseorang berasal dari mana dengan menyimak lafal dan kosakata yang digunakan dalam berbahasa kedua.

\section{Kajian Pustaka}

Penelitian tentang Interferensi leksikal ini sebelumnya pernah dilakukan oleh Indryana (2010) dengan judul penelitian "Interferensi Leksikal Bahasa Inggris Dalam Penggunaan Bahasa Indonesia Di Majalah Kawanku", penelitian ini membahas tentang penggunaan diksi yang digunakan oleh penulis majalah Kawanku sering memasukkan unsur-unsur leksikal bahasa Inggris dalam penggunaan bahasa Indonesia untuk mewarnai penggunaan bahasa Indonesia dan menarik minat pembaca. Berdasarkan hasil penelitian, interferensi leksikal dapat melibatkan kata dasar, kata majemuk, kata berimbuhan dan kata ulang. Kelas kata yang didapatkan terdiri dari empat jenis kata, yaitu kata benda, kata kerja, dan kata sif at. Penyebab interferensi leksikal bahasa Inggris dalam penggunaan bahasa Indonesia di majalah Kawanku terbit 2015 nomor 216 adalah kurangnya kosakata dalam bahasa Indonesia dan untuk menarik minat pembaca. Perbedaan penelitian sebelumnya dengan penelitian ini terletak pada sumber data penelitian yang digunakan, dimana penelitian ini akan mengambil sumber dari vlog Youtube.

\section{Hasil dan Pembahasan}

Dari data yang telah dikumpulkan sebelumnya, penulis membagi analisis bentuk interferensi leksikal ke dalam dua klasifikasi, yakni interferensi leksikal dalam bahasa Inggris dan interferensi leksikal dalam bahasa Mandarin. 


\subsection{Inteferensi Leksikal dalam Bahasa Inggris}

a. Dear (1) Onsu family (2)

Pada data (1) interferensi leksikal yang dilakukan oleh kenta adalah menggunakan kata "dear" di pembukaan suratnya. Kata "dear" ini merupakan bahasa Inggris yang umumnya digunakan sebagai pembuka dalam surat (baik surat elektronik maupun non elektronik) atau panggilan untuk orang-orang terdekat atau orang yang disayang. Dalam bahasa Indonesia kata “dear" ini memiliki arti 'sayang'. Bagi sebagian besar orang, baik penutur asing bahasa Indonesia maupun penutur asli bahasa Indonesia, kata "dear" ini lebih sering dan lebih akrab digunakan dalam kehidupan sehari-hari, sehingga tidak aneh bahwa kata "dear" ini lebih banyak digunakan dari pada kata "sayang".

Sementara itu untuk data (2) yakni kata family merupakan bentuk interferensi leksikal dalam bahasa Inggris. Kenta menggunakan kata "family" karena Ruben Onsu melabeli keluarganya dengan sebutan "Onsu Family". Oleh karena itu, sebenamya bukan hanya Kenta yang menyebutnya keluarga Ruben Onsu dengan sebutan "Onsu Family" tapi semua orang yang mengenal dan mengetahui keluarga tersebut, memanggilnya dengan sebutan "Onsu family". "Family" sendiri dalam bahasa Indonesia berarti 'keluarga'.

b. ayah terimakasih untuk saya dapat subscriber (3) nya 100rb

Bentuk interferensi leksikal yang terdapat pada data (3) yaitu interferensi leksikal dalam bahasa Inggris. Kata "Subscriber" pada data (3) dalam bahasa Indonesia berarti 'pelanggan'. Kata “subscriber" ini sangat umum digunakan oleh para pengguna aplikasi youtube khususnya pengguna aplikasi youtube di Indonesia. Kebiasaan orang Indonesia menggunakan kata "subscriber" itu membuat Kenta menganggap bahwa bahasa Indonesia tidak memiliki padanan dalam kata "subscriber", sehingga dia juga mengguanakan istilah yang sama untuk menyebut pelanggan aplikasi youtube.

c. Onyo terimakasih temenin saya terus, kita main banyak ya, berenang, main hoki, sama podcast (4) sore sering nonton youtube setiap hari. 
Bentuk interferensi leksikal yang terdapat pada kata "podcast" data (4) ini merupakan interferensi leksikal yang berasal dari bahasa Inggris. Kata "podcast" dalam bahasa Indonesia berarti 'siniar'. Kebiasaan menggunakan kata "podcast" menyebabkan orang Indonesia kesulitan mencari padanan kata dalam bahasa Indonesia. Hal tersebut membuat kata "siniar" tidak dikenal oleh masyarakat Indonesia. Mereka menganggap bahwa kata "podcast" adalah kata serapan dari bahasa Inggris. Oleh karena itu, meskipun podcast juga memiliki padanan kata dalam bahasa Indonesia, namun untuk mengganti penyebutan kata podcast ini sepertinya agak sulit untuk dilakukan.

d. Aunty (5) Wendy sama Uncle (6) Jordi terimakasih sudah baik sama saya dan sudah membantu saya untuk membuat $\operatorname{card}(7)$ ATM saya yang hirang.

Pada kata data (5) aunty, data (6) uncle, dan data (7) card termasuk ke dalam bentuk interferensi leksikal yang berasal dari bahasa Inggris. Kata-kata tersebut digunakan oleh Kenta karena kebiasaan dari keluarga Ruben Onsu memanggil Wendy dengan sebutaan "aunty" yang berarti 'bibi' dan juga memanggil Jordi dengan sebutan "uncle” yang berarti 'paman'. Sedangkan untuk kata "card” yang digunakan oleh Kenta, bisa jadi karena dalam bahasa Jepang untuk akhiran kata yang berakhiran " $u$ " biasanya huruf " $u$ " nya akan dilesapkan, sehingga mungkin saja yang dilafalkan Kenta adalah kata dalam bahasa Indonesia yaitu "kartu" namun karena huruf "u" nya dilesapkan maka terdengar seperti kata "card".

\subsection{Interferensi Leksikal dalam Bahasa Mandarin}

a. cici (8) taria terimakasih kita sering bikin rumah, bikin rumah-rumahan main masak-masakan, kasih semanggat untuk diet.

Pada data (8) yaitu kata "cici" merupakan bentuk interferensi leksikal yang berasal dari bahasa Mandarin yang berarti 'kakak perempuan'. Kata tersebut diucapkan oleh Kenta karena mengikuti kebiasaan keluarga Onsu yang memanggil Talia dengan sebutan cici sebagai kakak perempuan dikeluarga Ruben Onsu, sehingga pada saat pembacaan surat pun, Kenta memanggil Tania dengan kata cici. Pemanggilan kata "cici" ini disebabkan oleh Sarwendah yang merupakan ibu dari Talia ini memiliki keturunan China. 


\section{Simpulan}

Berdasarkan analisis yang telah dilakukan, maka dapat disimpulkan bahwa bentuk interferensi leksikal yang terjadi dalam vlog kenta berjudul "Kenta Pamit, Semua Nangis Denger Surat dari Kenta" diklasifikasikan menjadi 2 jenis, yaitu interferensi leksikal dalam bahasa Inggris yang berjumlah 7 data, yaitu "dear", "Onsu family", "subscriber", "podcast", "aunty", "uncle", dan "card", serta interferensi leksikal dalam bahasa China yang berjumlah 1 data yaitu "cici".

\section{Daftar Pustaka}

Chaer dan Agustina. 2010. Sosiolinguistik Perkenalan Awal. Jakarta: RinekaCipta

Darsita. S. 2014. "Penggunaan Kalimat Bahasa Indonesia oleh Mahasiswa Penutur Bahasa Asing”. Jurnal Al-Turaas. Jakarta:Universitas Negeri Jakarta. online. <http://journal.uinjkt.ac.id/index.php/al-turats/article/download/3759/2753>

Fitriasari, Lintang. 2011. "Interferensi Leksikal Bahasa Jawa dalam Penggunaan Bahasa Indonesia Ragam Lisan oleh Siswa TK ABA Perumnas Condongcatur.” Skripsi. Online. Yogyakarta: Universitas Negeri Yogyakarta. <http://eprints.uny.ac.id/22193/1/Lintang\%20Fitriasari\%2004210144022.pdf>

Ginting, Herlina dan Ginting, Adelina. 2019. “Beberapa Teori Dan Pendekatan Semantik”. Accessed March 11, 2021. <http://ejournal.ust.ac.id/index.php/PENDISTRA/article/download/594/pdfszx $\geq$

Indryana . 2019. “Interferensi Leksikal Bahasa Inggris Dalam Penggunaan Bahasa Indonesia Di Majalah Kawanku". Jurnal Bahasa dan Sastra (4): 79-85. Palu:Universitas Tadulako. online. <http://jurnal.untad.ac.id/jurnal/index.php/BDS/article/download/12228/9484>

Mariyana, Lisna. 2011. "Interferensi Leksikal Bahasa Indonesia dalam Bahasa Jawa pada Teks Berita Pawartos Jawi Tengah di Cakra Semangat TV." Skripsi. Universitas Negeri Semarang. Online < https://lib.unnes.ac.id/2779/1/6986.pdf> .

Onibala, Gareth. 2012. “Analisis Kesalahan Ortografis Bahasa Jerman pada Karangan Mahasiswa Program Studi Jerman Universitas Indonesia Angkatan 2011/2012.” Jurnal Metadata. Jakarta: Universitas Indonesia. Online. <http://lib.ui.ac.id/file?file=pdf/metadata-20298963.pdf $>$ 
Putri, Yuka Wirasa. 2014. "Interferensi Leksikal Bahasa Indonesia Dalam Bahasa Jawa Pada Karangan Narasi Siswa Kelas VII SMP Negeri I Bukateja Di Kabupaten Purbalingga”. Skripsi. Yogyakarta: Universitas Negeri Yogyakarta. Online. 〈https://core.ac.uk/download/pdf/33525741.pdf>

Rusyana, Y. 1988. Perihal Kedwibahasaan (Bilingualisme). Jakarta: FPS IKIP Bandung. 